\title{
Estrogen Receptor Staining Method
}

National Cancer Institute

\section{Source}

National Cancer Institute. Estrogen Receptor Staining Method. NCI Thesaurus. Code C122650.

An immunohistochemical technique used to detect the presence of estrogen receptor (ER) in a tissue sample. 